\title{
ONLINE ASSESSMENT IN THE LIGHT OF COVID-19-IMPOSED CHANGES IN HIGHER EDUCATION IN SERBIA 1
}

In this article, we present a qualitative analysis of online learning environments set up in response to the pandemic-induced lock down in higher education institutions in Serbia. The focus is on competence-based assessment approaches and the possibility of their implementation in higher education in Serbia. Through interviews with six teachers, we aim to outline some characteristics of higher education online courses and platforms used. Furthermore, we discuss the means of extending these approaches as to include online assessment. We also analyze prerequisites and issues in online assessment in the examined context. We argue that assessment in higher education is in a need of a profound change and could greatly benefit from the implementation of peer and self-assessment.

Keywords: online assessment, blended learning, higher education, technology in education, peer assessment, self-assessment.

\section{Introduction}

New approaches in assessment in higher education have attracted attention of stake holders and researchers alike. Bearing in mind the profound changes in learning and human interaction as well as the place that technology holds in contemporary society, a question of appropriate approaches to teaching and assessment arises. In this paper, we will present competence-based approaches to assessment and their possible implementation in higher education in Serbia. We will also discuss data gathered from interviews with professors from the Faculty of Philology, University of Belgrade in order to present some cases of online teaching as a response to Covid-19-imposed lockdown. Our main aim is to an-

\footnotetext{
* Univerzitet u Beogradu, Filološki fakultet, Studentski trg 3, 11000 Beograd; jovana-m@hotmail.com

1 The author of this paper is the recipient of a scholarship awarded by Ministry of Education, Science and Technological Development of the Republic of Serbia.
} 
alyze concepts of assessment that can be implemented in online teaching and analyze how they could be incorporated in higher education in Serbia regarding situations described in the interviews. We will present the reasons, methods, prerequisites and issues surrounding online assessment in higher education in Serbia.

\section{Grounds for changes in assessment}

Traditional assessment practices in higher education institutions have not radically evolved over the last two decades. In fact, as some researchers suggest, universities have maintained a conservative paradigm in this regard (Alonso et al. 2019: 173). This refers primarily to an assessment oriented towards measuring memory, facts and details, rather than competences and skills valuable in a variety of contexts (Struyven et al. 2005: 333; Medland 2016: 89). There are several possible reasons for this conservative approach. It is important to mention external factors that influence the current state of assessment practices. For instance, higher education staff is pushed to be as efficient as possible in order to meet external criteria such as growing number of students, and therefore growing workload, policy change, organizational requirements, limited budgets and time management demands (Norton et al. 2013: 243; Meyer et al. 2010: 345; Bearman et al. 2017: 57-58; Bourke 2018: 828). It is no wonder that due to all these restrictions, teaching staff often choose the assessment deemed most efficient and easy to implement, which does not always coincide with educational and pedagogical merit and can have limited validity (Meyer et al. 2010: 345; Price 2011: 483). This way of assessment has a direct effect on students, who concentrate on marks instead of deep and lasting learning (Nicol 2007: 669). With these constraints in mind, it is possible to wonder whether there is an impetus for change in assessment practices.

Despite certain challenges, the answer to this question is affirmative. Firstly, it is important to notice that teaching practices, which go hand in hand with assessment, have seen certain changes in recent years in higher education institutions in Serbia. Similar to the situation in other European countries, universities in Serbia have adopted the Bologna declaration and have chosen, at least on paper, to implement the idea of teaching competences and adhere to a framework which allows for a more personalized learning experience that allows international exchange and some degree of control of the curriculum on the student's part through elective courses. This change is expected to give grounds to improvement in assessment practices that share a common goal: equipping students for learning 
beyond the end of the course and giving them capacities to operate in challenging environments post-graduation (Boud \& Soler 2016: 410). Secondly, an important space for change has opened during the Covid-19 pandemics. Following the outbreak of the virus and the consequent lock-down in early 2020, universities in Serbia were forced to resort to online teaching, which led to discussions on the possibilities of online assessment as well. This sudden and unexpected change allowed the staff to experience online learning environments and face new sets of challenges and ideas through the process. We will discuss experiences from this period gathered through interviews in section Online courses in higher education in Serbia: a case of Covid-19-imposed response.

With all this in mind, it is clear that the traditional system is unsustainable and unfit for the current needs of students and society and is in need of a change. The question that arises is what kind of assessment is needed in order to meet the requirements of students and stakeholders alike.

\section{Learning for assessment or through assessment}

When discussing fundamental changes in higher education such as changes in assessment, it is necessary to rethink standard assessment in the form of a final exam. Given that studies indicate that final exams produce very low performance and lead to a significant amount of failing marks and students who do not appear on exam day (López-Pastor 2011: 37), other assessment models need to be taken into consideration. One possible way of approaching assessment in contemporary higher education consists of including students as agents, rather than objects of the activities in the process (Bourke 2018: 836). Whereas traditional final-exam-based assessment focuses on testing factual knowledge, with students being passive objects of that assessment, alternative models suggest that students can and should assume an active role in the process. There are two main paths of achieving this goal: self-assessment and peer-assessment. Self-assessment is an assessment process where students judge and make decisions about their own work using a particular set of criteria (Adachi et al. 2018: 295). This approach demands that the teacher and student work closely together on developing student's assessment skills and understanding of the criteria. Working in such a way can be time-consuming as it is crucial for the student to understand and implement a new concept of assessment on their own work. It is ultimately the student who does the assessment and through this, the student becomes the main participant of the process, as the teacher's role shifts towards that of an observer (Alonso et al. 2019: 71). 
Another possible approach worth mentioning is co-assessment. On the way towards self-assessment, there is an intermediary approach where students and teachers work on co-assessment. In this case, the student remains an active participant, but the assessment is mutually constructed between learners and assessors/ teachers (Boud \& Soler 2016: 402). Both the student and teacher work together through arguments in order to reach a mutually agreed mark for a given assignment (Bourke 2018: 830).

The second possible approach in assessment through competences is peer-assessment. Unlike self-assessment, peer-assessment focuses on students judging and deciding about the work of another, in this case their fellow students (Adachi et al. 2018: 295). Students are expected to anonymously evaluate one of their peer's work and by doing so, they have an opportunity to reflect and learn about different criteria and expectations. In the process of making progress, peer assessment can be equally important as teacher feedback (Nicol 2010: 514). Another benefit is the fact that peer-assessment can help students reflect on their own learning and understanding (Nortcliffe 2012: 14).

When it comes to implementing aforementioned assessment methods in the online world, some studies indicate that the digital environment can enhance these approaches (Deeley 2018: 440) as it is suitable for different kinds of assessment, including self and peer-assessment. These types of assessment are already common in MOOCs (Adachi et al. 2018: 297) and can be expanded to include comprehensive assessment in higher education. In either approach, which are by nature complementary, assessment literacy is essential and it is of great importance to work on developing a set of skills that would help the student gain a better understanding of assessment (Bourke 2018: 830). Moreover, students notably learn how to become more autonomous and how to learn with and from others (Adachi et al. 2018: 300). Despite the initial time cost of having to provide students with a different set of skills needed for an active role in the assessment process, Nicol (2010: 515) suggests that it is important take into consideration not just the costs, but also the benefits of these approaches in contrast to traditional assessment means. Some aspects of self and online peer-assessment will be further discussed in section Implementation of online assessment in higher education in Serbia, but in order to discuss it, we will firs outline some aspects of several online courses implemented as a part of higher education reaction to Covid-19 pandemic. 


\section{Online courses in higher education in Serbia: a case of Covid-19-imposed response}

In this section, we will present data collected from interviews with six informants working in higher education in Serbia. All six informants are currently teaching at the Faculty of Philology, University of Belgrade and are experts in language or literature studies. Four informants have a $\mathrm{PhD}$ and two informants have a Master's degree and are currently $\mathrm{PhD}$ candidates. Their academic rank varies accordingly: two informants are full professors, two are assistant professors, while two hold the title of teaching assistant and senior language instructor respectively. All informants have shown a particular openness towards online teaching and were selected based on their colleagues' recommendation and positive student experience during online classes. We will include additional information from interviews with professors working in the management of the University of Belgrade as rector and vice-rector respectively. At the time of writing the present article, the rector position was held by professor Ivanka Popović from the Faculty of Technology and Metallurgy, while the vice-rector position was held by professor Petar Bulat from the Faculty of Medicine. These two informants were included in order to provide a different perspective of the question at hand. The interviews were organized by the author of this article for non-scientific purposes. They are a part of a YouTube series UkljUči se (Get involved) (PAFF Produkcija Alumnija Filološkog Fakulteta 2020) created for the Alumni Association of the Faculty of Philology's online media channels. This online series discusses topics related to higher education, including online learning. As the series is available online and is therefore public material, we decided to use it for the present study because it sheds a new light on different teaching approaches adopted in response to Covid-19-imposed lock down and its effects on higher education in Serbia. It is important to state that the article does not examine student perspective related to online teaching. We believe that these interviews can be of interest for the scientific community as well as the general public towards whom the series was originally oriented.

During the interviews, all informants were asked questions on the following topics: previous experience with online teaching, current approach, platforms used, experience with online assessment, potentials for future online work, while the University's management also discussed legislative issues. We will present the data through a qualitative analysis of informants' answers and a discussion of some topics mentioned above. 


\subsection{Online platforms and software}

The informants from the Faculty of Philology used several online teaching platforms, some of which are not specifically intended for teaching purposes. The platforms and programs used are the following: Moodle, Zoom, Skype, DingTalk, Instagram, Power Point, Google Docs. The main platform used for online teaching is Moodle, a system designed specifically for academic purposes, which can be adapted to any specific higher education institution's needs. Faculty of Philology has its own Moodle environment and organizes regular staff trainings, so it is no wonder that this software is widespread. In the interviews, several ways of using this platform were mentioned. Firstly, Moodle was used as a shared space where teachers uploaded materials for students to consult and posted relevant information about the course, assessment, etc. (PAFF 2020: episodes 2, 4, 5). Secondly, Moodle was cited as a useful tool in the process of assessment as students were given assignments that were handed in through this platform (PAFF 2020: episodes 2, 4, 5). Additionally, in some instances, Moodle served not only for handing-in assignments, but also as a space for discussion or debate. Through forums available on the platform, students were given the possibility to analyze and discuss their peers' work or comment on important theoretical issues raised in proposed texts (PAFF 2020: episodes 4, 5). Lastly, some informants also used Moodle for testing (PAFF 2020: episodes $4,5)$, but in these cases, this was not a newly implemented method introduced during lock-down, but a standard practice that had already been used as a part of a blended-learning-oriented approach.

In addition to Moodle, some informants relied on Zoom as a means of live communication with students (PAFF 2020: episodes 2, 5). In the interviews, they revealed that Zoom allowed them to maintain live communication and teach classes similar to the courses held before the pandemic. Another potential use of Zoom was revealed during assessment where an informant maintained a video call with students as to ensure more ethical conduct and a continuous teacher support if needed. The same effect can be achieved through Skype or DingTalk, which had been used by one informant, who later turned to Zoom (PAFF 2020: episode 5).

Perhaps the most unusual platform evoked in the interviews was Instagram. This social media platform was used by one participant since it had proved to be adequate for interactive online learning (PAFF 2020: episode 2). A private Instagram account was created for the course at hand and different functionalities 
were adapted to meet learners' needs. Through the Instagram feed on the profile, students were able to get information, quotes and explanations on different course-related topics. Instagram live was used for online lessons which were available live in real-time and 24 hours following initial broadcast. Students were also given the possibility of participating in Instagram live broadcasts and could prepare content for the profile's stories, thus curating the account themselves.

Finally, it is important to mention some less complex platforms used by the informants. One informant used Google Docs as a method of communication and collaborative work platform where students could engage in discussions and create analyses, reviews and essays in cooperation with their peers (PAFF 2020: episode 2). What this platform offered in the case described above is the possibility to participate directly in the creation of a new document and easily track changes.

In addition to Google Docs, Power Point also proved to be a valuable tool. One informant used Power Point with voice over instead of live-streaming classes because this allowed students the freedom to access lectures at any given time and to adapt the pace to their own learning rhythm (PAFF 2020: episodes 4). Two other informants used Power Point during their course, but in this case, it was up to students to create and share their own presentations, as they would do in regular conditions in a classroom (PAFF 2020: episodes 4, 5).

From the data collected in the interview, it is visible that there is a wide choice of platforms that teachers can use in online education, but that each platform has its specificities. Informants typically used more than one platform or tool as they tried to meet the requirements of their course and its topic as well as the needs of students enrolled in the course.

\section{Implementation of online assessment in higher education in Serbia}

Bearing in mind the testimonies from participants presented in the previous chapter, it is necessary to discuss how experiences they described and methods they adopted can be further developed, especially in the area of assessment. When contemplating potential implementation of online assessment in higher education in Serbia, we need to take into consideration prerequisites for such a change, different modalities of assessment and potential issues that may arise. 


\subsection{Prerequisites}

When it comes to prerequisites, the initial condition to be met is related to legislation. Currently, the law on higher education in the Republic of Serbia does not allow students to take final exams outside of university premises. The first step towards online assessment would be a legislative change allowing this particular kind of assessment. Along with the law, there needs to be a new accreditation for programs that include online assessment, which is in the process as one informant stated during the interview (PAFF 2020: episode 2). Currently, at some faculties, such as the Faculty of Philology, accreditation only allows for blended learning (PAFF 2020: episode 4). This means that although final exams cannot be taken online, students can be evaluated in part through different activities that are submitted or done online (essays, different tasks on Moodle, etc.), which some informants use regularly in their practice.

Although legislation is an important and necessary step, the rector remarked that this step ought to come after a more profound change (PAFF 2020: episode 8 ). According to the rector, in order to adopt a new way of teaching and assessment, it is imperative to make radical changes in educational system as a whole (primary and secondary education, higher education). This change would include focusing on questions of ethics in education and the role of students and teachers. In the current system, students and teachers are often perceived as opponents rather than members of the same team working on a common goal. Instead of having knowledge and skills as the main reasons for studying, students are often too focused on formal success and are ready to ignore ethical boundaries on their quest for marks. Laws cannot change this perception and it is insufficient to change legislation without making these deeper transformations within the system.

Another important aspect of online teaching is technology. It is required that all participants in the process have a stable internet connection and adequate equipment. As one of the informants stated, certain platforms such as Zoom require a rather basic level of technology (PAFF 2020: episode 2), which means that students can participate via mobile devices and not only (more expensive) personal computers or laptops. Even though nowadays, most individuals own a smartphone, it is upon institutions to provide equipment for staff as well as underprivileged students if not all students. With proper equipment, another technological prerequisite is the internet connection which must be made available on the premises, but with distant learning, this does not suffice. Again, for underpriv- 
ileged students, it can be too expensive to pay for high-speed internet connection, so this must be addressed in some way.

Once the legislation and accreditation change in this regard and the right technology is put into use, the main prerequisite comes into focus: students' and teachers' expectations and habits. In order to adapt to online assessment, students and teachers need to be familiar with relevant technology and need to understand the principles of competence-oriented learning and assessment. According to Wanner \& Palmer (2018: 1044), the teacher is central to the successful implementation of formative self and peer-assessment. This can be true for online environment as well as teacher support is crucial and can help ease the transition to new ways of assessment. It is interesting to note that, according to some studies, there are opposing tendencies among teachers: teachers who resist using technology in assessment do not believe that their students have a necessary level of autonomy for such a task (Alonso et al. 2019: 178). This shows the need for special trainings for teachers and students alike. With relevant information and training, all participants can take part in online courses and assessment with less anxiety and more self-confidence.

\subsection{Some possibilities of implementing online assessment in higher education}

When all prerequisites are implemented, it is important to select one or several assessment methods that are appropriate for the given learning context. With the platforms mentioned by the informants in previous chapters, we can envisage several possible ways of using them in the assessment process. Firstly, it is important to state that we believe all approaches should rely on competences and not factual knowledge. This is needed because factual information can often be found quickly online and it would be challenging to control whether students are copying answers from online sources during a multiple-choice test done online from their homes. On the other hand, complex tasks involving different skills will provide students with knowledge useful in the workplace, beyond their studies, and are more difficult to copy and thus easier to control by the teacher. We will proceed to outline some possible implementations of such assessment.

With Moodle, the most popular platform among the informants, there are numerous possible ways of assessment. These range from tests to essays, with the teacher having the possibility of adjusting criteria to fit the specific context. For 
instance, in order to avoid cheating, tests can be done with a time-restriction ensuring that students do not dispose of enough time to look up every answer online, but that they have enough time to answer all questions. However, as previously stated, we believe that a competence-based approach is the best way of ensuring quality education and ethical standards by providing students with an occasion to express their critical thinking, original ideas and use of relevant sources. Students can therefore have tasks such as writing critical reviews of texts, essays on relevant topics, developing discussions on issues from a certain area, etc. These tasks can be done individually or in group and the end result can be submitted on Moodle. This is in accordance with one of the informants who advocates (PAFF 2020: episode 4) that open book exams can be a great way to ensure quality in higher education assessment.

With the use of Zoom or similar platforms, it is possible to hold group discussions regarding different topics and ensure student participation. As Zoom allows for simultaneous live discussions in different virtual rooms, this can be implemented as a means of multiple assessments taking place with different teachers at the same time. These online rooms can also be useful in team-oriented activities where students are invited to collaborate and are then in the position to evaluate their peers' involvement, for example. There is another significant benefit to be discussed. These online sessions have the advantage of being able to bring together peers from different towns or cities, but also different countries (PAFF 2020: episode 1). Through this kind of cooperation, we could organize peer to peer work and eventually assessment which brings together students from diverse backgrounds.

When it comes to social media, such as Instagram mentioned in this article, they have invaded all areas of life, so it shouldn't come as a surprise to see it in assessment. Instagram live can be used not only for teaching, but also for presenting results of students' work, individual or collaborative. Students can engage directly through the platform with their peers and present projects, discuss works they read, evolve their ideas. Other students could intervene in this situation and evaluate each presentation, with relevant arguments. This way, peer assessment can take place through a well-known platform most students use in their private life, which would provide a safe space and comfort to some students. Moreover, students can be given the task to present a relevant topic or issue through Instagram stories or Instagram live in a certain form that is required by Instagram's way of functioning. This type of constraint can help students learn how to adapt to different modalities of 
expression and how to address a certain audience, which are useful skills for a myriad of professional domains. Given that most institutions and business have an Instagram account, this could be a useful opportunity to gain some work skills. Although informants cited Power point or Google docs, we will not discuss them in this chapter as they are not independent platforms, but tools that can be used along with other online platforms.

\section{Issues in online assessment}

It is necessary to take into consideration possible issues in online assessment. The first potential issue is of technological nature. Unlike with live assessment, when students are assessed online in real time, online assessment can present some specific limitations. There can be breaks in the connection, which might compromise the assessment at hand. This type of problem was mentioned by one informant, who insisted that this problem is not common and that it can be overcome through a repeated assessment for students who experienced technical issues (PAFF 2020: episode 4).

The second issue that can influence online assessment is of socio-economic nature. As we previously mentioned, internet connection and devices needed for online learning and assessment can be costly. Unless higher education institutions provide all staff and students with equal access to necessary equipment, the move towards online learning can increase the socio-economic gap, especially among student population. This is a very complex issue that needs to be carefully examined and addressed. Additionally, costs can cause issues not only among students, but also in higher education institutions. As the rector evoked in her interview (PAFF 2020: episode 8), anti-plagiarism software that would ensure high standards in online assessment is expensive and for many higher education institutions, including those in Serbia, this type of software goes beyond the institutions' budget. This issue may consequently have an effect on the possibilities of successfully implementing this type of assessment.

The third issue lies in the feelings of students and teachers, as mentioned above. Certain teachers and students are not comfortable with using technology for this purpose and do not believe in merits of online assessment. This issue is closely related to conservative attitudes of teachers and students alike towards online assessment (or learning in general). These are also followed by anxiety and resistance towards using technology. Some students are not willing to easily 
accept new technologies, which may require effort to accept them (Deeley 2018: 443). Moreover, even though most students use technology in their private lives, some do not see its use in education and are not eager to use it in this area of their life (Deeley 2018: 443). These issues can be overcome with proper education and training for all individuals involved.

Lastly, an important issue is that of online control and surveillance. The problem that can arise with the use of technology in assessment is confidentiality and privacy-related. In fact, as Watson suggests (2017: 1041), online environment allows teachers to continuously follow their students' activity through analytics. This model is somewhat reductive and if not handled properly, it can cause negative feelings and attitudes in student population, most notably the feeling of constantly being controlled and quantified (Watson et al. 2017: 1042). It is upon higher education institutions to make sure that student data is being carefully handled and to provide students with a safe online environment. The teacher also needs to carefully approach this issue and avoid relying heavily on analytics, but rather use them in a favorable way.

Some of the aforementioned challenges can be overcome through training and education for all participants involved in the learning process. However, others cannot be easily resolved. As is the case with any type of assessment, there exist some issues that require time and effort. These issues need to be thoroughly examined and addressed, but they should not be the deciding factor in adopting online assessment in higher education. Through a thorough and well-planned approach, online assessment can be successfully implemented. Assessment should not be an afterthought, but a well-designed construction (Price 2011: 482).

Stakeholders need to focus on quality and appropriate methods of achieving this goal. This involves not only assessment, but the entire education process as assessment is not independent from teaching. Technology is an important tool, but not the aim of approaches we described. As it could be seen in teachers' testimonies, it is possible to integrate technology in higher education even in less-than-favorable conditions, such as the sudden Covid-19 crisis. It is imperative to examine and learn from experiences from this period and use them in order to improve the quality of higher education as a whole. This kind of assessment can help students better prepare for their future professional challenges and can provide them with a set of skills relevant to the 21 st century, which is ultimately one of the main goals of education. 


\section{Conclusion}

In this article, we examined different approaches and platforms used in online teaching at the Faculty of Philology, University of Belgrade and discussed possibilities of expanding these approaches to include online assessment. We argued that competence-based approaches should be in the focus of higher education institutions as they provide students with valuable skills that go beyond educational settings. We analyzed and presented data collected from interviews with six language teachers from the Faculty of Philology. Based on their experience in the Covid-19-imposed online teaching, we discussed different software that can be used in higher education and we then outlined possible assessment models relevant for the platforms that the informants used. We also discussed prerequisites and issues in online assessment. As the present research only takes into consideration experiences of professors and university management, we believe that it would be of great benefit to further examine online assessment practices by conducting further research with students as informants. We concluded that there are numerous ways of approaching online learning and assessment and it is important to take into consideration different platforms, different competence-based approaches in assessment and different needs of both students and teachers. With a careful and well-planned curriculum, it is possible to radically change traditional assessment methods and introduce an approach that prepares students for challenges well beyond educational contexts.

\section{REFERENCES}

Adachi et al. 2018: C. Adachi, J. H.-M. Tai, \& P. Dawson, Academics' perceptions of the benefits and challenges of self and peer assessment in higher education. Assessment \& Evaluation in Higher Education, 43(2), 294-306. Alonso et al. 2019: R. R. Alonso, I. R. Plaza, \& C. H. Orfali, Barriers in teacher perception about the use of technology for assessment in Higher Education. Digital Education Review, 35, 170-185.

Bearman et al. 2017: M. Bearman, P. Dawson, S. Bennett, M. Hall, E. Molloy, D. Boud, \& G. Joughin, How university teachers design assessments: A cross-disciplinary study. Higher Education, 74(1), 49-64.

Boud \& Soler 2016: D. Boud, \& R. Soler, Sustainable assessment revisited. Assessment \& Evaluation in Higher Education, 41(3), 400-413. 
Bourke 2018: R. Bourke, Self-Assessment to Incite Learning in Higher Education: Developing Ontological Awareness. Assessment \& Evaluation in Higher Education, 43(5), 827-839.

Deeley 2018: S.J. Deeley, Using technology to facilitate effective assessment for learning and feedback in higher education. Assessment \& Evaluation in Higher Education, 43(3), 439-448.

López-Pastor 2011: V.M. López-Pastor, Best practices in academic assessment in higher education: A case in formative and shared assessment. Journal of Technology and Science Education, 1.

Medland 2016: E. Medland, Assessment in higher education: Drivers, barriers and directions for change in the UK. Assessment \& Evaluation in Higher Education, 41(1), 81-96.

Meyer et al. 2010: L. Meyer, S. Davidson, L. McKenzie, M. Rees, H. Anderson, R. Fletcher \& P.M. Johnston, An Investigation of Tertiary Assessment Policy and Practice: Alignment and Contradictions. Higher Education Quarterly, 64(3), 331-350.

Nicol 2007: D. Nicol, Laying a foundation for lifelong learning: Case studies of e-assessment in large 1st-year classes. British Journal of Educational Technology, 38(4), 668-678.

Nicol 2010: D. Nicol, From monologue to dialogue: Improving written feedback processes in mass higher education. Assessment \& Evaluation in Higher Education, 35(5), 501-517.

Nortcliffe 2012: A. Nortcliffe, Can students assess themselves and their peers?: a five year study. Student Engagement and Experience Journal [online], 1(2), 1-17. [http://shura.shu.ac.uk/7610/1/nortcliffe can_students_assess themselves.pdf]

Norton et al. 2013: L. Norton, B. Norton, \& L. Shannon, Revitalising assessment design: What is holding new lecturers back? Higher Education, 66(2), 233-251.

Price et al. 2011: M. Price, J. Caroll, B. O’Donovan \& C. Rust, If I was going there I wouldn't start from here: a critical commentary on current assessment practice. Assessment \& Evaluation in Higher Education, 36(4), 479-492.

Struyuven et al. 2005: K. Struyven, F. Dochy, \& S. Janssens, Students' perceptions about evaluation and assessment in higher education: A review. Assessment \& Evaluation in Higher Education, 30(4), 325-341. 
Wanner \& Palmer 2018: T. Wanner \& E. Palmer, Formative self-and peer assessment for improved student learning: The crucial factors of design, teacher participation and feedback. Assessment \& Evaluation in Higher Education, 43(7), 1032-1047.

Watson et al. 2017: C. Watson, A. Wilson, V. Drew \& T.L. Thompson, Small data, online learning and assessment practices in higher education: A case study of failure? Assessment \& Evaluation in Higher Education, 42(7), $1030-1045$.

\section{Electronic sources}

PAFF 2020: PAFF Produkcija Alumnija Filološkog fakulteta, UkljUči se [online], episodes 1, 2, 4, 5, 8. [https://www.youtube.com/watch?v=jAHHSli3QJQ 


\section{Jovana Milovanović}

\section{ONLAJN EVALUACIJA U NOVONASTALIM USLOVIMA USLED KOVIDA-19 U VISOKOM OBRAZOVANJU U SRBIJI}

\section{Rezime}

Predmet ovog rada su modaliteti onlajn nastave koji su uvedeni u visokoškolskim institucijama u Srbiji usled pandemije Kovida-19 i mogućnosti evaluacije putem interneta koje proističu iz navedenog vida nastave. $U$ radu najpre prikazujemo konzervativnu praksu prisutnu u visokom obrazovanju, te ukazujemo na značaj uvođenja inovacija kako u nastavni proces, tako i evaluaciju. Posebnu pažnju posvećujemo vidovima evaluacije podsticajnim za razvijanje veština kod studenata, poput autoevaluacije i vršnjačke evaluacije. Prikazom intervjua sa šest predavača na Filološkom fakultetu Univerziteta u Beogradu i rektorkom Univerziteta u Beogradu nastojimo da prikažemo neke aspekte onlajn nastave koja je usled pandemije virusa Kovid-19 uvedena na univerzitete u Srbiji. Takođe, ukazujemo na platforme koje su intervjuisani predavači koristili i njihovu primenu u nastavi. Pored karakteristika onlajn nastave, razmatramo mogućnosti uvođenja onlajn evaluacije na visokoškolskom nivou, te upućujemo na preduslove za implementaciju ovog vida evaluacije. Najzad, analiziramo moguće poteškoće i probleme koji se javlaju prilikom učenja putem interneta. U radu ističemo da su potrebne korenite promene u univerzitetskom obrazovanju, a da bi autoevaluacija i vršnjačka evaluacija mogle biti značajni elementi u unapređenju obrazovnog sistema.

Ključne reči: onlajn evaluacija, kombinovano učenje, visoko obrazovanje, tehnologija u obrazovanju, vršnjačka evaluacija, autoevaluacija 